\title{
The Key Constraints of Innovation Strategies for Clustered Firms: On the Perspective of Global Value Chain
}

\author{
Lei Wang \\ Glorious Sun School of Management \\ Donghua University \\ Shanghai, China \\ wanglei7296@dhu.edu.cn
}

\author{
Hongxin Yao \\ Glorious Sun School of Management \\ Donghua University \\ Shanghai, China \\ yaohongxin@dhu.edu.cn
}

\begin{abstract}
This paper draws on cluster innovation theory to recognize key factors impacting two types of innovation mode of clustered firms. An index system of the factors impacting clustered firms`innovation is provided on the perspective of micro (enterprise), medium(cluster and GVC), and macro (government). Analytic Hierarchy Process (AHP) is used to quantify the weight of each factor. The results show that in the four first-level indexes, clustered firms' abilities are the key factor to impact their innovation strategies. According to the comparison among the second indexes, ten of them, including R\&D capability, marketing capability, GVC governance, and so on,have significant influences on the their innovation strategies. Our findings have theoretical and practical implications for cluster research in general.
\end{abstract} Mode

Keywords-Global Value Chain, Clustered Firms, Innovation

\section{INTRODUCTION}

In traditional research framework, theories about cluster innovation were concentrated on the knowledge transfer and innovation network, which formed three literatures about network environment(Steven Casper,2007)[1] 、 resource ability (Jean-Marc Callois , 2009) [2], and knowledge spillover(Effie Kesidou, Henny Romijn2008)[3]. However, the rapid development of globalization weakens the characteristic of the regionalization and localization. Embedding in global value chain $(\mathrm{GVC})$ to take part in international division proves to be a useful way for clusters to improve the regional competence and cope with challenges coming from globalization(Gereffi 1999)[4]. Therefore, scholars begin to research the localized cluster from the perspective of globalization. For example, Humphrey, J. \&Schmitz,(2008) [5] analyzed the different performances of the clusters drawing on theory of GVC. Federica Saliola and Antonello Zanfei(2009)[6] testified the effect of knowledge transfer on industry cluster based on globalized R\&D network. The empirical study of Oliver and Garrigos(2008) [7] indicates the technology spillover will be stronger in a cluster. Crestanello and Tattara[8], through their open innovation model, pointed out that ubiquitous knowledge spillover in GVC helps local firms obtain advanced knowledge, which will consequently improve their innovation performances.

The literature from perspective of globalization offers a better view for the research of cluster innovation(Morrison, Pietrobelli ,Rabellotti,2008)[9]. But there are still some shortcomings of extant theory. First, research on the cluster innovation has largely focused on the effecting factors in GVC.Very little is known about the issue which one of them determines innovation performance of clustered firms. The synthesized effection of these factors is also ignored. This is especially relevant as cluster innovation will be impacted by many factors in $\mathrm{GVC}$, it is difficult to explain the innovation strategy of clusters from a single factor. The key constraints shall be figured out for a better understanding of cluster innovation.Second, existing literature ignores the different type of innovation of clustered firms, hence, fails to distinguish the different effect of these factors on different type of innovation of clustered firms.Hence, further research must be made to classify the type of innovation of cluster ed firms. This paper,therefore, divides clustered firms innovation into independent innovation and imitative innovation, constructs an index system of the factors impacting from perspective of micro (enterprise), medium view(cluster and GVC), and macro view(government), uses the Analytic Hierarchy Process (AHP) to find out key constraints of innovation strategy for clustered firms.

The remainder of the paper is structured as follows. The next section describes methodology we used in this paper. We then outline the procedures we used to collect and analyze our data and provide the results. The results are then discussed in Section 4. Section 5 provides the conclusions, limitations of the study, and suggestions for future research.

\section{METHODOLOGY}

On the perspective of global value chain, choices of the innovation mode in the local clusters are affected by many factors, such as enterprise strategy, the regional environment, macroeconomic policy and value chain relationships and so on. In order to make the right selection, the key constraints of the cluster innovation must be found. So we construct an index system of the factors effecting the cluster innovation and get the key constraints of the cluster innovation by AHP, settle base for deeply research of the cluster innovation in the GVC.

Analytic Hierarchy Process(AHP) is a multi-factor analysis method which integrates qualitative and 
quantitative analysis together. Based on mathematics and psychology, the AHP was developed by Thomas L. Saaty in the 1970s and has been extensively studied and refined since then. It's suitable to evaluate the results difficult for direct and accurate measurement. As the factors affecting firm innovation in clusters involve a large number of qualitative evaluations, it is difficult to find alternative quantitative indicators to measure. Therefore, we use AHP to compare the relative weigh of different factors to identify the key constraints of firm innovation in clusters.

\section{RECOGNITION OF KEY CONSTRAINTS OF THE CLUSTER INNOVATION}

\section{A. Index System of the Factors Effecting the Cluster Innovation}

We deeply analyses the factors effecting innovation mode of industry clusters On the perspective of global value chain based in former research, and construct an index system of the factors effecting the cluster innovation from micro view(enterprise), medium view(cluster and GVC), and macro view(government).

TABLE I. INDEX SYSTEM OF FACTORS AFFECTING FIRM INNOVATION IN CLUSTER

\begin{tabular}{|c|c|c|}
\hline \multirow{12}{*}{$\begin{array}{l}\text { Global } \\
\text { value } \\
\text { chain } \\
\text { A1 }\end{array}$} & \multirow{2}{*}{$\begin{array}{c}\text { The } \\
\text { technical } \\
\text { control } \\
\text { trend } \\
\mathrm{B} 1\end{array}$} & $\begin{array}{l}\text { patent, the control of core } \\
\text { technology }\end{array}$ \\
\hline & & $\begin{array}{l}\text { brand, the control of market } \\
\text { channels }\end{array}$ \\
\hline & \multirow{3}{*}{$\begin{array}{l}\text { Governa } \\
\text { nce } \\
\text { B2 }\end{array}$} & market-based type \\
\hline & & balanced type \\
\hline & & seized type and level type \\
\hline & \multirow{2}{*}{$\begin{array}{l}\text { Independ } \\
\text { ence of } \\
\text { the } \\
\text { subsidiar } \\
\text { iesB3 }\end{array}$} & $\begin{array}{l}\text { strong independence: the } \\
\text { resources mainly supplied by the } \\
\text { multinational companies }\end{array}$ \\
\hline & & $\begin{array}{l}\text { weak independence: the resources } \\
\text { mainly supplied by the cluster }\end{array}$ \\
\hline & \multirow{2}{*}{$\begin{array}{c}\text { Evolutio } \\
\mathrm{n} \text { phases } \\
\text { of the } \\
\text { network } \\
\text { B4 }\end{array}$} & $\begin{array}{l}\text { vertical integration phase, vertical } \\
\text { interaction phase }\end{array}$ \\
\hline & & $\begin{array}{c}\text { vertical and horizontal (two-way) } \\
\text { interaction phase and network } \\
\text { phase }\end{array}$ \\
\hline & \multirow{3}{*}{$\begin{array}{l}\text { Embedde } \\
\text { d degree } \\
\text { B5 }\end{array}$} & $\begin{array}{c}\text { if the leading firms supply market } \\
\text { and technical information }\end{array}$ \\
\hline & & $\begin{array}{l}\text { if the leading firm supply } \\
\text { technical training }\end{array}$ \\
\hline & & $\begin{array}{l}\text { if the leading firms develop } \\
\text { products with local firms together }\end{array}$ \\
\hline Cluster & Social & trust and commitment \\
\hline
\end{tabular}

\begin{tabular}{|c|c|c|}
\hline \multirow[t]{10}{*}{$\begin{array}{c}\text { Cluster } \\
\text { A2 }\end{array}$} & $\begin{array}{l}\text { capital } \\
\text { B6 }\end{array}$ & $\begin{array}{l}\text { similar cultural background is } \\
\text { easier for communication }\end{array}$ \\
\hline & \multirow{2}{*}{$\begin{array}{l}\text { Regional } \\
\text { market } \\
\text { B7 }\end{array}$} & scale of regional market \\
\hline & & demand of regional clients \\
\hline & \multirow{2}{*}{$\begin{array}{l}\text { Innovativ } \\
\text { e } \\
\text { capabilit } \\
\text { y } \\
\text { B8 }\end{array}$} & $\begin{array}{l}\text { the intensity of the colleges, } \\
\text { research centers and the firm } \\
\text { R\&D centers }\end{array}$ \\
\hline & & $\begin{array}{l}\text { the relationship between the R\&D } \\
\text { institutions and the cluster } \\
\text { members }\end{array}$ \\
\hline & \multirow{2}{*}{$\begin{array}{l}\text { Type of } \\
\text { the } \\
\text { cluster } \\
\text { B9 }\end{array}$} & $\begin{array}{l}\text { the high-tech industry cluster: like } \\
\text { IT }\end{array}$ \\
\hline & & $\begin{array}{l}\text { the traditional industry cluster: } \\
\text { like the textile industry }\end{array}$ \\
\hline & \multirow{3}{*}{$\begin{array}{l}\text { Maturity } \\
\text { of the } \\
\text { cluster } \\
\text { network } \\
\text { B10 }\end{array}$} & $\begin{array}{l}\text { introduction period: the local } \\
\text { network haven't formed }\end{array}$ \\
\hline & & $\begin{array}{l}\text { maturity period: the local network } \\
\text { mainly form up }\end{array}$ \\
\hline & & $\begin{array}{l}\text { recession period: the appearance } \\
\text { of evil competition like the price } \\
\text { war }\end{array}$ \\
\hline \multirow{8}{*}{$\begin{array}{l}\text { enterp } \\
\text { rise } \\
\text { A3 }\end{array}$} & \multirow{2}{*}{$\begin{array}{c}\text { R\&D } \\
\text { capabilit } \\
\text { y } \\
\text { B11 }\end{array}$} & the technological basis \\
\hline & & the technical talent \\
\hline & \multirow{2}{*}{$\begin{array}{l}\text { Manufact } \\
\text { uring } \\
\text { capabilit } \\
\text { y B12 }\end{array}$} & $\begin{array}{c}\text { capability of learning } \\
\text { technologies }\end{array}$ \\
\hline & & $\begin{array}{l}\text { capability of introducing, } \\
\text { digesting and absorbing }\end{array}$ \\
\hline & \multirow{2}{*}{$\begin{array}{l}\text { Marketin } \\
\mathrm{g} \\
\text { capabilit } \\
\mathrm{y} \\
\text { B13 }\end{array}$} & the ability to expand the market \\
\hline & & the ability to build the brand \\
\hline & \multirow{2}{*}{$\begin{array}{l}\text { Strategic } \\
\text { orientatio } \\
n \\
\text { B14 }\end{array}$} & $\begin{array}{l}\mathrm{R} \& \mathrm{D} \text { orientation: the } \mathrm{R} \& \mathrm{D} \text { ability } \\
\text { is the key element to determine } \\
\text { the core competencies }\end{array}$ \\
\hline & & $\begin{array}{l}\text { market orientation: the marketing } \\
\text { capability is the key element to } \\
\text { determine the firm to be } \\
\text { successful or not }\end{array}$ \\
\hline \multirow{6}{*}{$\begin{array}{l}\text { extern } \\
\text { al } \\
\text { enviro } \\
\text { nment } \\
\text { A4 }\end{array}$} & \multirow{2}{*}{$\begin{array}{l}\text { Intellectu } \\
\quad \text { al } \\
\text { property } \\
\text { protectio } \\
\text { n B15 }\end{array}$} & $\begin{array}{c}\text { completeness of the intellectual } \\
\text { property protection laws }\end{array}$ \\
\hline & & $\begin{array}{l}\text { Intensity of intellectual property } \\
\text { protection }\end{array}$ \\
\hline & \multirow{2}{*}{$\begin{array}{l}\text { Policy } \\
\text { B16 }\end{array}$} & $\begin{array}{c}\text { Financial supporting policy of } \\
\text { technical innovation }\end{array}$ \\
\hline & & $\begin{array}{c}\text { financial subsidies policy of } \\
\text { technical innovation }\end{array}$ \\
\hline & \multirow{2}{*}{$\begin{array}{l}\text { Market } \\
\text { B15 }\end{array}$} & external market changes too fast \\
\hline & & $\begin{array}{c}\text { industry technology changes too } \\
\text { fast }\end{array}$ \\
\hline
\end{tabular}




\section{B. Determination of the Weight of Indexes}

Firstly, providing 1-9 scale to measure the different cases of index comparison.

Secondly, using Delphi method to do pairwise comparison of indexes, and getting a comparison matrix $A($ aij) to indicate the relative importance.

TABLE II. THE REFERENCE TABLE OF PROPORTIONAL SCALE WITH DIFFERENT CLASSIFICATION

\begin{tabular}{|c|c|}
\hline Value $\left(x_{i} / x_{j}\right)$ & explanation \\
\hline 1 & $\begin{array}{r}\text { Index } x_{i} \text { and } x_{j} \text { have same } \\
\text { importance }\end{array}$ \\
\hline 3 & $\begin{array}{c}\text { Index } x_{i} \text { has a little more } \\
\text { importance than } x_{j}\end{array}$ \\
\hline 5 & $\begin{array}{c}\text { Index } x_{i} \text { is obviously important } \\
\text { than } x_{j}\end{array}$ \\
\hline 7 & $\begin{array}{c}\text { Index } x_{i} \text { is strongly important } \\
\text { than } x_{j}\end{array}$ \\
\hline 9 & $\begin{array}{c}\text { Index } x_{i} \text { is extremely important } \\
\text { than } x_{j}\end{array}$ \\
\hline $2,4,6,8$ & correspond to the middle situation of two \\
adjacent judgments
\end{tabular}

Thirdly, calculating the index weight by using the data from the comparison matrix A, as:

1) Summing each column of matrix.

$$
a_{. j}=\sum_{i}^{n} a_{i j} \quad(i 、 j=1,2, \ldots n)
$$

2) Dividing every data in the matrix by the corresponding column, and getting a new normalized comparison matrix by column

$$
A^{*}\left(a_{i j}^{*}\right) \circ a_{i j}^{*}=\frac{a_{i j}}{a_{. j}} \quad(i, j=1,2, \ldots n)
$$

3) Calculating mean value of each row in $A^{*}\left(a_{i j}^{*}\right)$, then getting the weight of each

$$
\text { index. } \quad \mathrm{W}_{\mathrm{i}} \cdot \mathrm{W}_{\mathrm{i}}=\frac{\sum_{\mathrm{j}}^{\mathrm{n}} \mathrm{a}_{\mathrm{ij}}^{*}}{n}(\mathrm{i} 、 \mathrm{j}=1,2, \ldots \mathrm{n})
$$

At last, doing the consistency checking of the comparison matrix.

The greater the value of consistency index C.I. is, the greater the degree of deviation between the comparison matrix and the complete consistency will be. On the contrary, if the value of C.I. is smaller, the comparison matrix will be closer to the complete consistency. As we see in Table 3, our results show that the consistency is in the permitted range and the results are valid.
TABLE III. The average random consistency index

\begin{tabular}{|c|c|c|c|c|c|}
\hline $\mathbf{n}$ & 1 & 2 & 3 & 4 & 5 \\
\hline $\mathbf{R I}$ & 0 & 0 & 0.58 & 0.9 & 1.12 \\
\hline $\mathbf{n}$ & 6 & 7 & 8 & 9 & \\
\hline $\mathbf{R I}$ & 1.24 & 1.32 & 1.41 & 1.46 & \\
\hline
\end{tabular}

\section{Results}

Using the above method to confirm the weight of all the indexes, we can conclude the sequence of the weights for the factors affecting the choices of the innovative mode. (Table 4 -Table 8)

\begin{tabular}{|c|c|c|c|c|c|c|}
\hline & A1 & A2 & A3 & A4 & weight & \multirow{5}{*}{$\begin{array}{l}\lambda_{\max }=4.02 \\
\text { CR=0.0075 } \\
\text { The result } \\
\text { meets the } \\
\text { consistency. }\end{array}$} \\
\hline A1 & 1 & 3 & $1 / 5$ & 5 & 0.2318 & \\
\hline $\mathbf{A 2}$ & $1 / 3$ & 1 & $1 / 5$ & 3 & 0.1995 & \\
\hline $\mathbf{A 3}$ & 5 & 5 & 1 & 7 & 0.3985 & \\
\hline A4 & $1 / 5$ & $1 / 3$ & $1 / 7$ & 1 & 0.1702 & \\
\hline
\end{tabular}

TABLE IV. THE COMPARISON MATRIX AND THE CONSISTENCY CHECKING FOR A1-A4

\begin{tabular}{|c|c|c|c|c|c|c|c|}
\hline & B1 & B2 & B3 & B4 & B5 & $\begin{array}{c}\text { weig } \\
\text { ht }\end{array}$ & $\begin{aligned} \lambda_{\max } & =4.02 \\
\mathrm{RR} & =\mathbf{0} 0075\end{aligned}$ \\
\hline B1 & 1 & $1 / 7$ & $1 / 9$ & $1 / 3$ & 1 & 0.2334 & The result \\
\hline B2 & 7 & 1 & $1 / 9$ & $1 / 5$ & 7 & 0.2906 & meets the \\
\hline B3 & 9 & 9 & 1 & 7 & 7 & 0.1414 & consistency. \\
\hline B4 & 3 & 5 & $1 / 7$ & 1 & 3 & 0.1344 & \\
\hline B5 & 1 & $1 / 7$ & $1 / 7$ & $1 / 3$ & 1 & 0.2101 & \\
\hline
\end{tabular}

TABLE V. THE COMPARISON MATRIX AND THE CONSISTENCY CHECKING FOR B1-B5

\begin{tabular}{|c|c|c|c|c|c|c|c|}
\hline & $\begin{array}{l}\text { B } \\
6\end{array}$ & B7 & B8 & B9 & $\begin{array}{c}\text { B } \\
10\end{array}$ & weight & \multirow{6}{*}{$\begin{array}{l}\lambda_{\max }=5.2581 \\
\text { CR=0.0576 } \\
\text { The result } \\
\text { meets the } \\
\text { consistency. }\end{array}$} \\
\hline B6 & 1 & $1 / 4$ & $1 / 7$ & $1 / 9$ & $1 / 7$ & 0.0652 & \\
\hline B7 & 4 & 1 & 5 & $1 / 7$ & $1 / 5$ & 0.1452 & \\
\hline B8 & 7 & $1 / 5$ & 1 & $1 / 6$ & $1 / 7$ & 0.1142 & \\
\hline B9 & 9 & 7 & 6 & 1 & 5 & 0.4108 & \\
\hline B10 & 7 & 5 & 7 & $1 / 5$ & 1 & 0.2646 & \\
\hline
\end{tabular}

TABLE VI. THE COMPARISON MATRIX AND THE CONSISTENCY CHECKING FOR B6-B10

\begin{tabular}{|c|c|c|c|c|c|c|}
\hline & B11 & B12 & B13 & B14 & weight & \multirow{5}{*}{$\begin{array}{l}\lambda_{\max }=4.1421 \\
\text { CR=0.0532 } \\
\text { The result } \\
\text { meets the } \\
\text { consistency. }\end{array}$} \\
\hline B11 & 1 & 7 & 1 & 7 & 0.3929 & \\
\hline B12 & $1 / 7$ & 1 & $1 / 7$ & 5 & 0.1445 & \\
\hline B13 & 1 & 7 & 1 & 5 & 0.3555 & \\
\hline B14 & $1 / 7$ & $1 / 5$ & $1 / 5$ & 1 & $\begin{array}{l}0.1071 \\
\end{array}$ & \\
\hline
\end{tabular}

TABLE VII. THE COMPARISON MATRIX AND THE CONSISTENCY CHECKING FOR B11-B14 
TABLE VIII. THE COMPARISON MATRIX AND THE CONSISTENCY CHECKING FOR B15-B17

\begin{tabular}{|c|c|c|c|c|c|}
\hline & B15 & B16 & B17 & weight & $\lambda_{\max }=\mathbf{3 . 0 1 7 8}$ \\
\hline B15 & 1 & $1 / 5$ & $1 / 7$ & 0.1483 & $\mathrm{CR}=\mathbf{0 . 0 1 7 1}$ \\
\hline B16 & 5 & 1 & $1 / 5$ & 0.2889 & The result \\
\hline B17 & 7 & 5 & 1 & 0.5627 & $\begin{array}{l}\text { meets the } \\
\text { consistency. }\end{array}$ \\
\hline
\end{tabular}

TABLE IX. THE SEQUENCE OF ALL INDEXES

\begin{tabular}{|c|c|c|c|}
\hline \multicolumn{2}{|c|}{\begin{tabular}{|l|l|} 
Enterprise A3 & 0.3985 \\
\end{tabular}} & \multirow{3}{*}{$\begin{array}{c}\text { R\&D capability B11 } \\
\text { marketing capability B13 } \\
\text { absorptive capability } \\
\text { B12 } \\
\end{array}$} & \multirow{2}{*}{\begin{tabular}{|l|}
0.3929 \\
0.3555 \\
\end{tabular}} \\
\hline & & & \\
\hline & & & 0.1445 \\
\hline & & strategic orientation B14 & 0.1071 \\
\hline \multirow{5}{*}{$\begin{array}{l}\text { Global value } \\
\text { chain } A 1\end{array}$} & \multirow[t]{5}{*}{0.2318} & governance B2 & 0.2906 \\
\hline & & $\begin{array}{l}\text { the technical control } \\
\text { trend of the leading firms } \\
\text { B1 }\end{array}$ & 0.2334 \\
\hline & & the embedded degree B5 & 0.2101 \\
\hline & & $\begin{array}{l}\text { the independence of the } \\
\text { subsidiaries B3 }\end{array}$ & 0.1414 \\
\hline & & $\begin{array}{l}\text { the evolution phases of } \\
\text { the network B4 }\end{array}$ & 0.1344 \\
\hline \multirow[t]{5}{*}{ Cluster A2 } & \multirow[t]{5}{*}{0.1995} & $\begin{array}{l}\text { the cluster type and the } \\
\text { nature of products B9 }\end{array}$ & 0.4108 \\
\hline & & $\begin{array}{l}\text { the maturity of the } \\
\text { cluster network B10 }\end{array}$ & 0.2646 \\
\hline & & regional market B7 & 0.1452 \\
\hline & & $\begin{array}{l}\text { the innovative capability } \\
\text { B8 }\end{array}$ & 0.1142 \\
\hline & & social capital B6 & 0.0652 \\
\hline \multirow{3}{*}{$\begin{array}{c}\text { External } \\
\text { environment } \\
\text { A4 }\end{array}$} & \multirow[t]{3}{*}{0.1702} & market B17 & 0.5627 \\
\hline & & policy B16 & 0.2889 \\
\hline & & $\begin{array}{c}\text { intellectual property } \\
\text { protection B15 }\end{array}$ & 0.1483 \\
\hline
\end{tabular}

\section{IV.DISCUSSION}

\section{Comparative Analysis of the First-level Indexes}

According to the comparison among the first-level indexes, the enterprise has the highest weight of 0.3985 , which indicates that although embedded in the global value chain expands the resource boundary of the enterprises, the innovative mode of the firms in the cluster is still affected by internal factors, such as research capacity, market capacity, strategic orientation, etc. The weight of global value chain is in the second place, for 0.2318 , which is highly above the cluster factor and external environmental factor. If the enterprises are embedded in the global value chain, it will be easier for them to get the international advanced knowledge, technology and information, and to have an important impact in choosing the innovation mode. This is consistent with the realistic experience of the late-developed countries. The weight of Cluster is 0.1995, indicating that on the background of the global value chain, this factor doesn't have significant impacts on the choices of the innovative decisions. The factor of external environment has the lowest weight. Compared with the other three factors, this one has the least impact.

\section{E. Comparative Analysis of the Second-level Indexes}

1) The enterprise:Through learning the existing research literatures, we divided the enterprise factor into four parts: R\&D capability, marketing capability, manufacturing capability and absorptive capability. According to the comparison among these four indexes, R\&D capability and marketing capacity have the highest weight of 0.3929 and 0.3555 respectively, totally more than $70 \%$. This indicates that the technological capability and the ability to open up the market are the key factors to decide the firm's choices of technological innovation. In contrast, the manufacturing capability and the absorptive capability have lower weights. This means formulation of the strategic orientation actually builds on the basis of their R\&D capability and marketing capacity.

2) The Global Value chain:According to the comparison among these five indexes, the governance and the technical control trend carried out by the multinational firms have higher weights of 0.2906 and 0.2334 respectively. This indicates that in the global value chain oriented by multinational firms, their strategic decision is the key factor to decide the choices of technological innovation. In addition, it shows that when the enterprises in developing countries embed into the global value chain, the choices of the technological innovation mode are always in the passive position. The embedded degree has the weight of 0.2101 . This means whether the subsidiaries embed into the cluster, and whether they build extensive and close relationship between the cluster members, are another important factor affecting the innovative choices. The independence of the subsidiaries and the evolution phases of the global value chain network have lower weights of 0.1414 and 0.1344 respectively. This means the above two factors have less influence on cluster innovation.

3) The Cluster:According to the comparison among these five indexes, the cluster type has the highest weight of 0.4108 . This means different industry has different technological innovative trend. The regional market has the weight of 0.2646 , which indicates that the scale of the local market and the demanding characteristics have important effects on the choices. The intellectual resources and the regional market take the second place, of 0.2792 and 0.2342 respectively. The social capital has the lowest weight. This result is different to the view stressed by many scholars who believe social capital has significant impact on the cluster innovation. The result indicates that although the formation of social capital has a certain influence on the cluster innovation, however, comparing with the cluster type, the regional market and other factors, its impact on cluster innovation is not so significant. 
4) The External Environment:According to comparison among these three indexes, the external market environment has the highest weight of 0.5627 , indicating that external market is the key factor to determine the choices of innovative mode. Almost all choices are determined by the market outlook and technical environment. The policy and the intellectual property protection have the weights of 0.2889 and 0.1483 respectively. The policy has higher impact than intellectual property protection. On the one hand, this means government plays a very important role in the innovative policy. On the other hand, this indicates that the intellectual property protection environment has changed a lot than before in China.

\section{CONCLUSION}

We conduct this study to provide a more nuanced perspective on the factors impacting clustered firms innovation strategies on the perspective of GVC. We argue that innovation of Clustered firms is the result of a complex interaction of firms abilities, cluster environment, foreign companys' strategies and other various factors.Hence,the key factors which impacting clustered firms' innovation strategies shall be found out. In that sense, We deeply analyses the factors impacting innovation mode of clustered firms On the perspective of GVC based on former research,constructs an index system of factors impacting clustered firms' innovation strategies on perspective of micro (enterprise), medium (cluster and GVC), and macro(government). The Analytic Hierarchy Process (AHP) iss used to quantify the weight of each factor and key factors is figured out.

The results show that in the four first-level indexes, clustered firms`abilities are the key factors to impact their innovation strategies, which indicates that the innovation mode of clustered firms is determined by firms` internal factors, such as research capacity, market capacity, strategic orientation, etc.. According to the comparison among the second indexes, ten of them, including R\&D capability, marketing capability, GVC governance, technical control bias of the leading firms, embeddedness degree, type of cluster, regional market and policies, have significant influences on the clustered firms innovation strategies, which means that they are the key factors to determine clustered firms' innovative choices.

This research draws on cluster innovation theory to recognize key factors impacting two types of innovation mode of clustered firms. Conclusions were drawn in the GVC context. However, There are also shortcomings in our study. First, we use the Delphi method to assign the weight of each factor, which is mainly based on subjective judgments of experts and scholars. Therefore, conclusions may be biased. Second, Second, the impacts of GVC embeddedness on innovation in clustered firms can exhibit their full potential in the long run. Hence, longitudinal studies may help test and substantiate some of the cross-sectional findings in the present study.Therefore, in our future research, we will choose a wide range of enterprises to do empirical research.

\section{ACKNOWLEDGMENT}

Foundation items: National Social Science Foundation of China (No. 10 CGJ024); National soft Science Foundation of China (No. 2010GXS5D202); the Fundamental Research Funds for the Central Universities of China.

\section{REFERENCES}

[1] Steven Casper. How do technology clusters emerge and become sustainable? : Social network formation and inter-firm mobility within the San Diego biotechnology cluster[J]. Research Policy, 2007, 36(4): 438-455

[2] Jean-Marc Callois. The two sides of proximity in industrial clusters: The trade-off between process and product innovation[J].Journal of Urban Economics. January 2008, 63(1):146-162

[3] Effie Kesidou, Henny Romijn Do Local Knowledge Spillovers Matter for Development? An Empirical Study of Uruguay's Software Cluster[J]. World Development. 2008,36(10): 2004-2028

[4] Gereffi, G. , Humphrey, J. \& Sturgeon, T. The Governance of GlobalValue Chains $[\mathrm{J}]$. Review of International Political Economy .2003,15(4):1121-1135

[5] Humphrey, J. and Schmitz, H.Inter-firm Relationships in Global Value Chains: Trends in Chain Governance and Their Policy Implications[J], International Journal of Technological Learning, Innovation and Development . 2008, 34(4):58-82

[6] Federica Saliola, Antonello Zanfei .Multinational firms, global value chains and the organization of knowledge transfer[J], Research Policy, Volume 38, Issue 2, March 2009, Pages 369-381

[7] Jose-Luis Hervas-Oliver , Jose Albors-Garrigos(2008). Local knowledge domains and the role of MNE affiliates in bridging and complementing a cluster's knowledge[J]. Entrepreneurship \& Regional Development. Vol.20, No.6, pp: 581-598

[8] Paolo Crestanello, Giuseppe Tattara.Industrial Clusters and the Governance of the Global Value Chain: The Romania-Veneto Network in Footwear and Clothing.Regional Studies. 2011,45(2): 187-203

[9] Morrison, A.; Pietrobelli C.; Rabellotti R (2008).Global value chains and technological capabilities: A framework to study industrial innovation in developing countries[J].Oxford Development Studies. Vol.36, No.1, pp: $39-58$ 